\title{
PENGAWASAN DINAS PEKERJAAN UMUM DAN PENATAAN RUANG DALAM ALIH FUNGSI LAHAN DI KECAMATAN CIMAHI UTARA KOTA CIMAHI
}

\author{
Irma Safei ${ }^{1}$ \\ ${ }^{1}$ Jurusan Ilmu Pemerintahan, Fakultas Ilmu Sosial dan Ilmu Politik, Universitas \\ Jenderal Achmad Yani
}

\begin{abstract}
Abstrak
Penelitian ini berjudul "Pengawasan Dinas Pekerjaan Umum dan Penataan Ruang Dalam Alih Fungsi Lahan Di Kecamatan Cimahi Utara Kota Cimahi”. Batasan masalah dalam penelitian ini adalah belum optimalnya pengawasan yang dilakukan oleh Dinas Pekerjaan Umum dan Penataan Ruang di Kawasan Bandung Utara, maka penelitian dapat merinci dengan mengidentifikasi masalah sebagai berikut: Bagaimana pengawasan Dinas Pekerjaan Umum dan Penataan Ruang Kota Cimahi dalam menjaga ketersediaan lahan agar tidak terjadi alih fungsi lahan secara terus menerus di Kecamatan Cimahi Utara? Metode yang digunakan dalam penelitian ini adalah metode penelitian deskriptif dengan pendekatan kualitatif, adapun teknik pengumpulan data dilakukan dengan observasi, wawancara, studi pustaka dan dengan mempelajari peraturan daerah yang berhubungan dengan penelitian ini, serta dilakukan teknik analisis data dengan tiga tahap yaitu reduksi data, penyajian data dan penarikan kesimpula. Pihak-pihak yang dijadikan narasumber dalam penelitian ini yaitu Kepala Seksi Pengendalian Pemanfaatan Tata Ruang, Camat Cimahi Utara dan staff Seksi Perizinan Pemanfaatan Ruang. Sedangkan instrumen utama dalam penelitian ini adalah peneliti sendiri. Berdasarkan hasil penelitian menunjukkan bahwa pertumbuhan penduduk menjadi salah satu faktor terjadinya alih fungsi lahan di Kecamatan Cimahi Utara, lalu pengawasan yang dilakukan oleh Dinas Pekerjaan Umum dan Penataan Ruang belum optimal sebab belum mampu bertindak sesuai dengan peraturan yang ada dan komitmen yang belum optimal dalam melaksanakan peraturan daerah sesuai dengan fungsi penataan ruang yang mengakibatkan alih fungsi lahan terjadi di Kawasan Bandung Utara Kecamatan Cimahi Utara Kota Cimahi.
\end{abstract}

Kata Kunci : Pengawasan, alih fungsi lahan, pertumbuhan penduduk dan komitmen

\begin{abstract}
This research is entitled "The Supervision Of Public Works and Spatial Planning In Over The Conversion Land In North Cimahi Subdistrict Of Cimahi City". The limitations problem in this study is not yet optimal controlling by Publick Works Control and Spatial Planning in the North Bandung Area. Then
\end{abstract}


the research can be detail by identification the problem as follow : How the controlling of Public Works and Spatial Planning of Cimahi City areas in maintainance the availability of land that conversion does not occur continuously in? The method used in this reseach by using descriptive method of analysis with qualitative approach. While the technique on data collection is done through, literature study, interview, observation and by studying the local regulation, and performed data analysis techniques with three stages of data reduction, data presentation and conclusion. The interview was conducted in this reseach to Head of the Spatial Use Control Section, Head of North Cimahi Subdistrict and Staff of Permissions The Spatial Section. While the main instrument in this reseach is the researcher themselves. Based on the result of the research is population growth became one of the facts of conversion land, controls conducted by Department of Public Works and Spatial Planning has not been optimal because it has not been able to act witch regulations and commitment to built in to implement local regulations with the spatial fungction which resulted in land conversion occurred in The Area of North Bandung; North Cimahi Subdistrict; Cimahi City.

Keywords : Controlling, Conversion land, population growth and commitment

\section{PENDAHULUAN}

Seiring pertumbuhan dan perkembangan peradaban manusia, maka penguasaan dan penggunaan lahan mulai beralih fungsi. Seperti halnya daerah perkotaan yang mempunyai fungsi dan peranan yang sangat penting dalam menopang pertumbuhan dan kemajuan di bidang perekonomian, terlebih lagi dalam kehidupan masyarakat. Dengan kondisi seperti itu, pemukiman penduduk terkonsentrasi di daerah perkotaan yang mengakibatkan arus urbanisasi penduduk ke kota dari tahun ke tahun terus mengalami peningkatan tetapi ketersediaan lahan tidak mengalami peningkatan ataupun perluasan.

Dalam hal ini, penggunaan lahan oleh setiap aktivitas pembangunan di sektor industri, permukiman dan jasa lainnya sedikitnya akan mengubah rona lingkungan awal menjadi rona lingkungan baru, sehingga terjadi perubahan kesinambungan lingkungan yang mengakibatkan adanya konversi lahan yang tidak dapat dicegah.

Selain adanya keterbatasan lahan, permasalahan tata ruang semakin rumit karena kondisi perekonomian pada saat ini semakin hari semakin pesat beriringan dengan pertumbuhan penduduk yang melonjak yang 
berimbas kepada tekanan penggunaan dan pemanfaatan ruang untuk pertumbuhan kawasan perumahan dan pemukiman. Lahan merupakan sumber daya alam yang strategis bagi pembangunan. Oleh sebab itu, hampir semua sektor pembangunan fisik memerlukan lahan, seperti sektor pertanian, perumahan, industri, pertambangan, transportasi, dll. Lahan menjadi salah satu unsur utama dalam menunjang kehidupan manusia. Hal tersebut dikarenakan penggunaan lahan yang tidak memperhatikan kemampuan lahan, daya dukung dan bentuk peruntukannya.

Beban alih fungsi lahan bagi pembangunan semakin tinggi karena menyangkut pemanfaatan lahan resapan air yang meliputi lahan pertanian perkotaan dan ruang terbuka hijau. Dalam prosesnya, alih fungsi lahan senantiasa berkaitan erat dengan ekspansi atau perluasan kawasan perkotaan. Persoalan sumber daya lahan yang dinilai cukup serius belakangan ini adalah alih fungsi lahan produktif yang cukup besar. Alih fungsi lahan berlangsung secara terus menerus sejalan dengan peningkatan pembangunan dan transformasi ekonomi yang ditandai pergeseran peran antar sektor menuntut alih fungsi lahan dalam jumlah yang tidak sedikit.

Dalam hal ini Pemerintah Provinsi Jawa Barat membuat perhatian khusus terhadap Kawasan Bandung Utara karena wilayah tersebut sangat berpotensi terjadinya alih fungsi lahan, sebab kawasan tersebut memiliki nilai guna yang sangat berpengaruh bagi wilayah Bandung Raya. Sehingga pemerintah Provinsi Jawa Barat membuat aturan untuk kawasan tersebut yang diatur di dalam Peraturan Daerah Nomor 2 Tahun 2016 tentang Pengendalian Kawasan Bandung Utara (KBU). Berdasarkan peraturan tersebut, fenomena alih fungsi lahan di Kota Cimahi terutam Kecamatan Cimahi Utara merupakan dampak dari transformasi pertumbuhan penduduk yang semakin meningkat yang pada akhirnya mendorong transformasi sumberdaya lahan yang seharusnya dijadikan lahan resapan air tetapi beralih fungsi menjadi perumahan. Selain itu ketidak tegasan pemerintah dalam mengimplementasikan aturan yang membuat pemilik 
lahan dengan mudah mengkonversi lahan tanpa mempertimbangkan peruntukan dayaguna lahan tersebut di dalam peraturan.

Terlebih Kota Cimahi sebagai daerah yang cukup padat penduduknya. Permasalahan timbul ketika pertumbuhan penduduk tidak dapat dihentikan banyak pihak yang memanfaatkan untuk mendirikan perumahan di kawasan yang seharusnya menjadi wilayah resapan air. Alih fungsi lahan adalah proses pengalihan penggunaan lahan dari penggunaan semula ke penggunaan selanjutnya.

Pertumbuhan penduduk memerlukan lahan yang semakin luas, hal tersebut dibutuhkan sebagai lahan untuk pemukiman. Seperti contohnya di Kecamatan Cimahi Utara terdapat perumahan yang sudah berdiri cukup lama yaitu perumahan Kamarung Regency, dimana perumahan tersebut belum mengantongi izin dari pemerintah tetapi sampai saat ini tidak ada tindak tegas dan pengawasan yang dilakukan oleh pemerintah Kota Cimahi. Hal itu menjadi sebuah permasalahan sebab perumahan tersebut berada di wilayah Cimahi Utara yang notabene wilayah tersebut termasuk ke dalam Kawasan Bandung Utara. Perubahan penggunaan lahan tersebut atau dikenal sebagai alih fungsi lahan tentu saja akan memberikan dampak pada lingkungan dimana alih fungsi lahan tersebut terjadi.

Dengan timbulnya permasalahan tersebut maka pemerintah Kota Cimahi dengan keterbatasan lahan yang dimiliki, pemerintah tidak mampu melaksanakan perencanaan kota secara komprehensif sesuai dengan peruntukan lahan tersebut. Sesuai dengan peraturan Daerah Nomor 4 tahun 2013 tentang rencana Tata Ruang Wilayang Kota Cimahi Tahun 2012-2032 dalam bab 1 pasal 1, menjelaskan bahwa : "Kawasan Bandung Utara yang selanjutnya disingkat KBU adalah kawasan yang meliputi sebagaian wilayah Kabupaten bandung, Kota Bandung, Kota Cimahi dan Kabupaten Bandung Barat." Maka wilayah Kecamatan Cimahi Utara dengan memiliki luas $13,3 \mathrm{~km}^{2}$ yang berbatasan langsung dengan Kabupaten Bandung Barat yang termasuk ke dalam Kawasan Bandung Utara terus mengalami peningkatan pembangunan perumahan, akibatnya wilayah resapan air tersebut mengalami banyak perubahan yang berimbas 
kepada wilayah yang seharusnya menjadi tempat resapan air menjadi kawasan perumahan penduduk. Hal tersebut dapat terjadi karena kurangnya pengawasan dari pemerintah, dimana pemerintah yang memeliki peran dalam mengawasi Kawasan Bandung Utara ialah Dinas Pekerjaan Umum dan Penataan Ruang. Dalam hal ini Dinas Pekerjaan Umum dan Penataan Ruang memiliki tugas seperti: memberi sosialisasi tentang penggunaan lahan, memberikan peringatan, himbauan dan teguran terhadap pemilik pemukiman ataupun perumahan yang tidak sesuai dengan peraturan izin terbatas mendirikan bangunan di Kawasan Bandung Utara. Hal tersebut seharusnya menjadi perhatian dan diawasi secara serius oleh dinas terkait. Masalah tata ruang, adalah suatu fakta bahwa jumlah penduduk serta kebutuhan yang semakin meningkat baik secara kualitatif maupun secara kuantitatif. Seperti halnya di wilayah Kecamatan Cimahi Utara yang sebagian wilayahnya masuk kedalam Kawasan Bandung Utara dimana hal itu harus mampu lebih diperhatikan oleh pemerintah akan guna lahan tersebut agar tidak dimanfaatkan sebagai wilayah yang menguntungkan pihak-pihak tertentu saja.

Faktor yang mempengaruhi alih fungsi lahan di Kota Cimahi antara lain semakin meningkatnya kebutuhan lahan, sehingga mengakibatkan harga tanah naik secara tajam. Serta peraturan mengenai penataan ruang pertanahan yang belum dilaksanakan dengan tegas, sehingga terdapat celah untuk alih fungsi lahan. Pesatnya pembangunan yang mengakibatkan terjadinya alih fungsi lahan yang dihadapkan pada persoalan-persoalan seperti yang berkaitan dengan lahan di Kecamatan Cimahi Utara, yang melatar belakangi penelitian ini yaitu:

1. Pertumbuhan penduduk yang terus meningkat dengan keberadaan terbatasnya ketersediaan lahan.

2. Pemanfaatan dan pengelolaan lahan serta pola tata ruang yang belum sepenuhnya dilaksanakan secara terpadu dan menyeluruh.

3. Penggunaan lahan seringkali terjadi penyimpangan dari peruntukannya.

4. Masih rendahnya kesadaran hukum masyarakat terhadap kepatutan atas kewajiban sebagai warga negara. 


\section{METODE PENELITIAN}

Metode yang digunakan dalam penelitian ini adalah penelitian deskriptif dengan pendekatan kualitatif. Penelitian deskriptif adalah penelitian yang bertujuan untuk membuat suatu penjelasan, gambaran atau lukisan sistematis, faktual dan akurat mengenai fakta-fakta, sifat-sifat serta fenomena yang diselidiki. Analisis dilakukan terhadap data yang diperoleh berdasarkan kemampuan nalar dalam menghubungkan fakta, data dan informasi.

Dalam penelitian ini tidak menabukan pendekatan kuantitatif, karena tidak dapat dipungkiri data berbasis angka juga akan didapatkan dalam penelitian ini, sehingga akan dihasilkan pembahasan yang lebih komprehensif. Menurut Moloeng (2010:6) menjelaskan bahwa : Penelitian kualitatif merupakan penelitian yang bermaksud memahami fenomena tentang apa yang dialami oleh subjek penelitian misalnya perilaku, presepsi, motivasi, tindakan dan lain secara holistik dan dengan cara deskriptif dalam bentuk kata-kata dan bahasa, pada suatu konteks khusus yang alamiah dan dengan memanfaatkan berbagai metode alamiah.

\section{HASIL DAN PEMBAHASAN}

Fenomena alih fungsi lahan di Kota Cimahi terutam Kecamatan Cimahi Utara merupakan dampak dari transformasi pertumbuhan penduduk yang semakin meningkat yang pada akhirnya mendorong transformasi sumber daya lahan yang seharusnya dijadikan lahan resapan air tetapi beralih fungsi menjadi perumahan. Seiring dengan pertambahan penduduk maka kebutuhan akan lahan pun semakin meningkat. Perubahan penggunaan lahan atau dikenal sebagai alih fungsi lahan tentu saja akan memberikan dampak pada lingkungan dimana alih fungsi lahan tersebut terjadi. Selain itu ketidak tegasan pemerintah dalam mengimplementasikan aturan yang membuat pemilik lahan dengan mudah mengkonversi lahan tanpa mempertimbangkan peruntukan dayaguna lahan tersebut di dalam peraturan. Dan juga kurangnya pengawasan dari 
pemerintah yang mengakibatkan pembangunan di wilayah resapan air terus berlanjut tanpaada kontrol. Alih fungsi lahan adalah proses pengalihan penggunaan lahan dari penggunaan semula ke penggunaan selanjutnya. Proses alih fungsi lahan tidak dapat dihindari dari setiap wilayah yang sedang berkembang.

Dalam hal ini Dinas Pekerjaan Umum dan Penataan Ruang yang memiliki kewenangan dalam mengawasi keberadaan perumahan di wilayah Kawasan Bandung Utara yang terletak di Kecamatan Cimahi Utara Kota Cimahi. Sehingga didalam pembahasan ini peneliti membahas hasil penelitian yang akan menganalisis data-data yang diperoleh dari penelitian yang telah dilakukan, baik yang dilakukan melalui studi literatur maupun penelitian yang dilakukan di lapangan melalui wawancara kepada informan yang berkaitan dengan penelitian yang dilakukun, mengenai "Pengawasan Dinas Pekerjaan Umum dan Penataan Ruang dalam Alih Fungsi Lahan di Kecamatan Cimahi Utara Kota Cimahi", untuk memperjelas pembahasan sekaligus mempermudah penjelasan dan hasil penelitian maka terdapat dimensi dan indikator yang digunakan oleh peneliti dalam membantu peneliti dalam mendeskripsikan atau menjelaskan bagaimana pengawasan yang dilakukan oleh Dinas Pekerjaan Umum dan Penataan Ruang dalam alih fungsi lahan di Kecamatan Cimahi Utara Kota Cimahi terlaksana sesuai dengan tahap-tahap dalam proses pengawasan yang dikemukakan oleh Handoko (2015: 360-363) sebagai berikut:

\section{Peraturan yang berlaku}

Penataan ruang sebagai suatu proses perencanaan tata ruang, pemanfaatan ruang, pengawasan serta pengendalian pemanfaatan ruang merupakan suatu satu kesatuan sistem yang tidak dapat terpisahkan antara satu dan yang lainnya. Untuk menciptakan suatu penataan ruang yang sesuai peruntukannya maka memerlukan suatu peraturan perundangan-undangan yang serasi diantara peraturan tingkat pusat sampe peraturan tingkat daerah, sehingga terjadinya suatu koordinasi dalam penataan ruang yang sesuai dengan guna fungsi peruntukannya. 
Hasil observasi peneliti dalam pengawasan yang dilakukan oleh Dinas Pekerjaan Umum dan Penataan Ruang maka penetapan standar ialah dengan melaksanakan peraturan yang sesuai dengan rencana tata ruang wilayah agar dapat terlaksana penataan ruang sesuai dengan semestinya. Dengan menetapkan peraturan hal itu dilakukan sebagai landasan yang digunakan untuk penilaian yang diperoleh. Peneliti mengamati peraturan daerah yang ada di Kota Cimahi tentang rencana tata ruang wilayah sudah baik tetapi dalam mengimplementasikan peraturan daerah tersebut belum sepenuhnya terlaksana sebab di wilayah Kecamatan Cimahi Utara terdapat perumahan yang belum mengantongi izin tetapi dapat berdiri dengan tidak memperhitungkan dengan zonasi peruntukan Kecamatan Cimahi Utara yang termasuk ke dalam Kawasan Bandung Utara.

Analisis dari hasil wawancara dengan narasumber dan juga hasil observasi bahwa penetapan standar pelaksana yang dilakukan adalah dengan mengimplementasikan peraturan daerah mengenai rencana tata ruang wilayah yaitu Peraturan Daerah Kota Cimahi Nomor 4 tahun 2013 tentang RTRW Kota Cimahi Tahun 2012-2032 dimana didalamnya mengatur tentang Kecamatan Cimahi Utara dan juga tercantum bahwa Kota Cimahi terutama Kecamatan Cimahi Utara termasuk ke dalam Kawasan Bandung Utara. Hal tersebut terdapat korelasi dengan Peraturan Daerah Provinsi Nomor 2 tahun 2016 bahwa Kota Cimahi khususnya Kecamatan Cimahi Utara adalah bagian dari Kawasan Bandung Utara, yang memiliki zonasi penataan ruangnya sebagai kawasan resapan air dan perumahan kepadatan rendah.

\section{Proses penetapan standar izin}

Kebutuhan akan tempat hunian (perumahan) yang semakin tinggi mengakibatkan terjadinya alih fungsi lahan yang tidak dapat dihindari, terutama di Kecamatan Cimahi Utara yang wilayahnya masuk ke dalam Kawasan Bandung Utara memiliki aturan yang membatasi peruntukan perumahan dan pemukiman sebab wilayah tersebut masuk ke dalam wilayah cekungan Bandung yang salah satu fungsinya ialah sebagai wilayah resapan air. Di Kecamatan Cimahi Utara diperbolehkan mendirikan 
suatu perumahan dengan kepadatan rendah sesuai dengan peraturan daerah yang telah ditetapkan.

Dari hasil observasi peneliti bahwa perkembangan perumahan di kecamatan Cimahi Utara semakin meningkat walaupun dengan penetapan standar izin khusus dan pembangunan terbatas, hal tersebut dihiraukau oleh para pengembang sebab standar izin khusus untuk wilayah tersebut dan tanpa mengantongi izin pun sampai saat ini terdapat perumahan yang belum mengantongi izin dan masih berdiri bahkan semakin berkembang dan maju. Fenomena tersebut terjadi karena lemahnya pengawasan yang dilakukan oleh dinas terkait dengan peraturan yang ada di Kota Cimahi.

Analisis dari wawancara dan observasi di lapangan yang peneliti lakukan yang berkaitan dengan Bagaimana pengawasan yang dilakukan Dinas Pekerjaan Umum dan Penataan Ruang dalam menajga resapan air di KBU yang terletak di Kecamatan Cimahi Utara. maka dapat disimpulan, maka dapat disimpulkan bahwa pengawasan yang dilakukan oleh dinas terkait ialah dengan mengimplementasikan peraturan daerah yang relevan dan juga dengan mengeluarkan izin tertentu untuk Kecamatan Cimahi Utara agar tidak terjadialih fungsi lahan yang mengakibatkan kawasan untuk resapan air semakin berkurang di Kawasan Bandung Utara. Tetapi pada nyatanya yang terjadi di lapangan ialah bahwa pertumbuhan atau peningkatan akan perumahan semakin pesat di wilayah kecamatan Cimahi Utara bahkan terdapat perumahan yang belum memiliki izin setelah 5 tahun berdiri dan tidak ada pengawasan yang dilakukan oleh dinas terkait, dalam hal ini kecamatan selaku yang memiliki wilayah tidak berhak memberikan sanksi tetapi kecamatan memberi pembinaan dan mengingatkan bahwa keberadaan perumahan tersebut ilegal karena tidak terdapat izinnya.

Maka dalam hal ini fakta di lapangan dan hasil dari wawancara belum mencapai kesesuaian yang semestinya dilaksanakan, sebab penetapan standar izin yang ada sudah baik jika dilaksanakan dengan semestinya yang mengakibatkan terdapat perumahan yang tidak mengantongi izin sebab lemahnya pengawasan tersebut. Peraturan standar 
yang ada merupakansuatu satuan pengukuran yang dapat digunakan sebagai patokan aturan yang harus dilaksanakan, diterima dan ditegakkan secara tepat.

\section{Tahap-tahap yang harus dilaksanakan dalam perizinan}

Penentuan pengukuran pelaksanaan kegiatan dilakukan untuk mengukur kegiatan yang dilaksanakan secara nyata dan kegiatan secara tepat. Begitupun dalam pengawasan, bahwa pengawasan bisa berjalan dengan baik jika terdapat tahapan-tahapan standar yang dapat mengukur pengawasan tersebut. Dalam fenomena alih fungsi lahan yang terjadi di Kecamatan Cimahi Utara maka yang harus dilaksanakan untuk kegiatan pengawasan yaitu dengan cara memberikan tahapan-tahapan dalam proses perizinan dalam membuat perumahan. Kota Cimahi sendiri dalam hal memberikan perizinian berhubungan langsung dengan DPMPTSP dan jika perizinan yang diajukan dalam skala besar seperti berhubungan dengan pembuatan perumahan maka akan berhubungan juga dengan DPUPR karena untuk meninjau penataan ruangnya. Dengan tahapan yang cukup panjang dan selektif tersebut membuat maraknya berdiri perumahanperumahan baru di Kecamatan Cimahi Utara yang dibangun secara ilegal tanpa memperhatikan tata ruang wilayah kegunaan fungsi lahan tersebut yang masuk ke dalam Kawasan Bandung Utara.

Dapat disimpulkan bahwa dari hasil wawancara dengan narasumber dan juga hasil observasi peneliti di lapangan bahwa proses yang harus dilalui untuk dapat memanfaatkan ruang terutama di wilayah Kecamatan Cimahi Utara yang termasuk kedalam Kawasan Bandung Utara ialah sesuai dengan Peraturan Daerah Kota Cimahi Nomor 16 Tahun 2012 tentang Penyelenggaraan Perizinan Tata Ruang. Dimana dalam awal sekali seseorang untuk meminta izin ialah bukan membangun terlebih dahulu tetapi mereka meminta izin prinsip, izin prinsip diberikan sebagai persetujuan untuk menggunakan ruang serta memberikan arahan umum terhadap penggunaan ruang yang dimohon dari aspek tata ruang, aspek lingkungan, aspek teknis bangunan gedung, aspek ekonomi dan sosial budaya sebagai pedoman pemberian izin pemanfaatan ruang lainnya. 
Izin Prinsip bukan merupakan izin untuk memulai kegiatan pembangunan dan harus ditindaklanjuti dengan Izin Pemanfataan Ruang lainnya. Setelah izin prinsip keluar maka masih terdapat izin-izin lainnya yang harus dilalui untuk dapat mendirikan bangunan yang sesuia dengan standar untuk Kawasan Bandung Utara. Dengan peraturan yang bahwa Kawasan Bandung Utara yang seharusnya mengutamakan sebagai kawasan resapan air dengan kepadatan penduduk rendah tetapi pada nyatanya masih terdapat perumahan yang belum mengantongi izin yaitu perumahan Kamarung Regency yang sudah ada sejak 5 tahun yang lalu dan saat ini sudah banyak penghuni yang berdomisili di perumahan tersebut. Hal tersebut sangat berbanding terbalik dengan peraturtan yang ada sebab terjadi alih fungsi lahan yang berlebihan yang mengganggu ekosistem lingkungan sekitarnya. Dengan keberadaan perumahan yang berdiri dengan ilegal (tanpa izin) maka perumahan tersebut tidak sesuai dengan zonasi peruntukannya dan mengakibatkan terjadinya alih fungsi lahan.

\section{KESIMPULAN}

Dengan memiliki standar pelaksanaan yaitu melalu peraturan Daerah Nomor 4 Tahun 2013 tentang Rencana Tata Ruang Wilayah Kota Cimahi tahun 2012-2032 maka hal tersebut dapat meminimalisir terjadinya pemanfaatan ruang yang tidak sesuai, terutama di Kecamatan Cimahi Utara yang termasuk kedalam Kawasan Bandung Utara maka sangat membantu wilayah tersebut agar tetap sesuai peruntukan fungsinya yaitu sebagai kawasan resapan air. Selain itu juga Peraturan Daerah Provinsi Jawa Barat Nomor 2 Tahun 2016 tentang Pengendalian KBU, sangat jelas bahwa Kawasan Bandung Utara merupakan wilayah yang betul-betul sangat dijaga karena sangat berpotensi dan berpengaruh untuk keseimbangan wilayah Bandung Raya.

Terdapatnya penentuan pengukuran pelaksanaan kegiatan hal tersebut membantu Dinas Pekerjaan Umum dan Penataan Ruang dalam 
meminimalisir terjadinya alih fungsi lahan di Kawasan Bandung Utara yaitu dengan cara tahap-tahap yang dilakukan dalam permohonan pengeluaran izin berbeda zonasinya dengan wilayah lain yang ada di Kota Cimahi sebab wilayah Kecamatan Cimahi Utara peruntukan hunian ataupun perumahannya adalah wilayah dengan kepadatan rendah, KDB maksimalnya yaitu 30\% dan Ruang Terbuka Hijau minimum untuk wilayah Kecamatan Cimahi Utara adalah $52 \%$ itu semua terdapat di dalam Peraturan daerah Kota Cimahi Nomor 16 tahun 2012 tentang Penyelenggaraan Perizinan Penataan Ruang.

Dari hasil penelitian bahwa pemerintah sudah melakukan prosedur sesuai dengan peraturan yang berlaku tetapi dalam hal pengawasannya yang dilakukan masih kurang optimal sebab ditemukannya perumahan yang belum memiliki izin tetapi dapat berdiri tanpa tindak lanjut sesuai dengan peraturan yang berlaku. Dengan adanya peraturan daerah yang mengatur tentang tata ruang wilayah Kota Cimahi, aturan tersebut ada agar penataan ruang di Kota Cimahi dapat sesuai peruntukannya dan tidak terjadi alih fungsi lahan. Dalam hal ini koordinasi yang dilakukan oleh dinas-dinas terkait sudah cukup optimal dalam mengeluaran izin sesuai dengan peraturan penyelenggaraan penataan ruang di Kot Cimahi.

\section{REKOMENDASI}

Alih fungsi lahan terjadi karena kurangnya pengawasan yang dilakukan oleh pemerintah. Pemerintah juga belum optimal dalam menegakkan peraturan daerah yang berlaku. Selain itu kesadaran masyarakat akan kegunaan lahan tidak peduli karena tingkat kebutuhan akan hunian dan pemukiman di Kota Cimahi semakin meningkat. Perlunya kerjasama yang dilakukan oleh pemerintah dan masyarakat dalam menjaga kesesuaian lahan sesuai dengan fungsinya. Ketegasan pemerintah dalam memberikan tindakan sangat dibutuhkan agar dapat menghindari terjadinya alih fungsi lahan yang terus menerus terjadi di Kota Cimahi khususnya di Kecamatan Cimahi Utara Kota Cimahi. Dalam hal ini pemerintah juga harus mampu mensosialisasikan kepada masyarakat agar masyarakat juga mengetahui tentang peraturan yang berlaku dan seperti 
apa prosedur yang harus dilakukan oleh masyarakat agar sesuai dengan peraturan yang berlaku.

\section{DAFTAR PUSTAKA}

Hasibuan, Malayu Parlagutan. 2014. Manajemen Dasar, Pengertian, Dan Masalah. Jakarta: Bumi Aksara.

Handayaningrat, Soewarno. 1996. Pengantar Studi Ilmu Administrasi dan Manajemen. Jakarta: PT Toko Gunung Agung.

Irwan, Zoer'aini Djamal. 2012. Prinsip-prinsip Ekologi : Ekosistem, Lingkungan dan Pelestariannya. Jakarta: Bumi Aksara.

Ridwan, Juniarso. 2016. Hukum Tata Ruang. Bandung: Nuansa.

Moleong, Lexy, J. 2012. Metode Penelitian Kualitatif. Bandung: Remaja Rosdakarya.

Ndraha, Taliziduhu. 2015. Kybernology : Ilmu Pemerintahan Baru. Jakarta: PT Rineka Cipta.

Makmur. 2015. Efektivitas Kebijakan Kelembagaan Pengawasan. Bandung. PT Refika Aditama.

Purwowidodo. 1983. Teknologi Mulsa. Bandung: Angkasa.

Handoko, Hani. 2015. Manajemen Edisi 2. Yogyakarta. BPFE.

Sugiyono. 2012. Memahami Penelitian Kualitatif. Bandung: PT Alfabeta. 